scheme for the investigation of lathyrism, and notes on suggested lines of work on shock, the segregation and treatment of cases of tetanus with the view of clinical trials of $V-187$ in India, on the classification of clinical tetanus, and on a technique for removal of the brain and spinal cord in cases of lathyrism are also given. There are also reports on the distribution of typhus fever in the army in India, 1943-46, and of the sub-committee appointed to examine the possibility of maintaining sickness absenteeism records in Indian industries.

\section{LATIN AMERICAN CULTURES}

$\mathrm{T}$ HE Institute of Social Anthropology, which has recently been formed within the Smithsonian Institution, has started to issue an important series of monographs*. The five which have so far appeared deal with Latin America and have a very wide range. Their object is both scientific and practical, and the co-operation afforded by the national authorities both in Mexico and in Peru is a measure of the importance which they ascribe to the work. Leaving aside No. 1, on houses and house use of the Sierra Tarascans, which was published so long ago as 1944, the following brief comments are intended to give some indication of the nature of the series.

Nos. 2 and 3 are detailed studies of a small highland town in Mexico and of a coastal town of the same order of magnitude on the coast of Peru. Although the people of Cherán are Tarascan Indians, with little white blood, speaking their native language and living principally by agriculture like their forefathers, the conclusion is reached that most traits of their culture are derived from Europe. This is not to say that it is a European culture, since the contact with indigenous Tarascan elements has caused it to develop into something distinct from either ; in fact, into what Mr. Gillin, in his monograph on Moche, would describe as a Creole culture.

Moche is by comparison a drab place, as the useful series of photographs in each publication will show, but Mr. Gillin's analysis proves that its culture contains a far higher proportion of indigenous elements. The town lies almost under the shadow of the two great pyramids of Moche, and, like them, owes its name to the ancient Mochica culture; but this had at least two successors before the Spanish Conquest, so it must not be expected that much of it has survived unmodified to the present time, as Mr. Gillin is careful to point out ; and the remaining aboriginal elements are common to a number of pre-Colombian cultures rather than specific to the Mochica. The difference between the two towns is well illustrated by the accounts given of witchcraft in each of them. The data for Cheran are far from complete, but what there are have a completely European aspect, whereas those for Moche, which are fuller, have a predominantly shamanistic complexion. In spite of the aboriginal survivals, however, the author shows that Moche has a Creole culture rather than an Indian one, but considers it likely that it has changed considerably in this sense during the past generation.

- 2. Cherán: A Sierra Tarascan Village. By Ralph L. Beals. Pp. $x+225+8$ plates. 3. Moche : a Peruvian Coastal Community By John Gillin. Pp. vii $+166+26$ plates. 4. Cultural and Historical Geography of Southwest Guatemala. By Felix Webster McBryde. Pp. xv+184+47 plates. 5. Highland Communities of Central Peru a Regional Survey. By Harry Tschopik, Jr. Pp. vili $+56+15$ plates 50 cents each. (Pub. 2-5 of the Institute
No. 5 is a preliminary study, undertaken in order to choose a suitable place for more detailed work. It brings out the great variety in degree of change from Indian to white culture which is found in the Central Andes of Peru. One of its most illuminating features is a discussion of what constitutes an Indian, showing that racial criteria are so difficult to apply that a cultural definition is generally the only practicable one. In addition to introductory matter, which includes general accounts of the geography and the population, the paper contains interesting brief descriptions of most of the places visited. The town of Sicaya was chosen for further study, on the ground that it demonstrated best the process by which an Indian acquires a Mestizo culture and the Mestizo a white culture.

No. 4 is a voluminous and well-illustrated work, containing the geographical materials which an anthropologist needs to build on, particularly with regard to the use of land, and which he too often has to neglect owing to lack of specialized training. It will, presumably, be followed up by more purely anthropological studies. G. H. S. BUSHNELI

\section{FORTHCOMING EVENTS}

(Meetings marked with an asterisk * are open to the public)

\section{Saturday, May I}

British Psyohological Society (in the Physiology Theatre, University College, Gower Street, London, W.C.1), at 2.30 p.m. Mr. David Katz: "Gestalt Laws of the Body Scheme".

\section{Monday, May 3} FARMERS' CLUB (at the Royal Empire Society, Craven Street,
Strand London, w. Strand, L

LONDON SCHOOL OF ECONOMICS AND POLITICAL Sclence (at Houghton Street, Aldwych, London, W.C.2), at 5 p.m.-Prof. Fran H. Knight: "Economic Theory and the Good Society". (Furcher Lectures on May 10, 24, 31, June 7 and 14.)*

SOCIETY of ENGINERRS (at the Geological Society, Burlington House Piccadilly, London, W.1) at $5.30 \mathrm{~m}$ m.-Mr. W. T. Winter "The Development of the Jet Propulsion Engine".

ChEMICAL SocteTY, LEEDS SEcTion (in the Chemistry Department, The University, Leeds), at 6.30 p.m.- Prof. Linus C. Pauling, For Mem.R.S.: "The Valence of Metals and the Structure of Intermetallic compounds".

SOCIETY OF CHeMTCAL INDUSTRY (at the Chemical Society, Burlington House, Piccadilly, London, W.1), at 6.30 p.m.-Annual General Meeting: Mr. B. A. Southgate: "The Treatment and Disposal of Waste Waters from Industry".

Monday, May 3-Friday, May 7

LIBRARY AsSOCIATTON (in the Spa Grand Hall, Scarborough).Annual Conference.

\section{Tuesday, May 4}

COENCll For the PRESERVATION OF RURAL Enguand (at the Royal Institution of Chartered Surveyors, 12 Great George Street, London, S.W.1), at 2.30 p.m.-Annual General Meeting.

BRITISH SOCIETY FOR THE HISTORY OF SCIENCE (at the Science Museum, Exhibition Road, London, S.W.7), at 5 p.m.-Annual General Meeting.

Royal ANTHROPOLOGICAL INSTITUTE (joint meeting with the INTERNATIONAR AFRICAN INSTTTUTE, at 21 Bedford Square, London, W.C.1), at 5 p.m.-Dr. Max Gluckman, Mr. J. H. Barnes and Mr. J. C. Mitchell: "The Village Headman in British Central Africa".

Society of Chemical Industry, Chemical EngInRERING Grodp (at the Geological Societv. Burlington House, Piccadilly, London W.1), at 5.30 p.m.-Dr. J. N. Pring:"Modern Propellants Employed in British Ordnance".

\section{Wednesday, May 5}

ROYAI SOcremY OF ARTS (at John Adam Street, Adelphi, Iondon, W.C.2), at 2.30 p.m.Dr. F. G. Mann, F.R.S. : "Recent Advances in Stereochemistry" (Pope Memorial Lecture).

PHYSIOAL SOCIFTY (at the Royal Institution, 21 Albemarle Street, London, W.1), at 4 p.m.-Annual General Meeting : at 5 p.m.-Prof. Yves Rocard: "Sur les conditions d"autooscillation des systèmes vibrants" (Third Holweck Discourse).

MaNchester Literary aNd Philosophical Soctety, Soctal PhILOSOPHY SEOTION (at the Portico Library, Manchester), at 5.30 p.m.-Prof. J. A. Hawgood: "Education in Germany"."

SOCTRTY OF PUBUIC ANALYSTS AND OTHER ANALYTICAT CHEMTSTS (at the Chemical Society, Burlington House, Piccadilly, London, W.1), at 7 p.m.-Scientific Papers. 